\title{
PENINGKATAN PEMAHAMAN BACAAN MAHASISWA MELALUI TEKNIK THINK-PAIR-SHARE BERBASIS LESSON STUDY
}

\author{
Made Aryawan Adijaya \\ Jurusan D3 Bahasa Inggris, Undiksha \\ E-mail: aryawan_aj@yahoo.com
}

\begin{abstract}
This research aims at improving the reading text comprehension of D3 English department of Ganesha University students through think, pair and share technique with lesson study basis, and finding out the students' response towards the implemented technique. It employes the teaching system development method with lesson study model by Lewis (2002). The research was done within 3 cycles due to limitation of time. Each cycle consists of 3 activities such as: 1) plan, 2) do, 3) see. The subjects were 12 students of D3 English department of Ganesha University at $4^{\text {th }}$ semester who took Reading 3 course. The data were gathered through observation, and evaluation taken from reading comprehension tests. The analysed data show that the students were very happy with the implemented technique, and felt motivated in doing all phases of learning. The improvement of students' reading comprehension was known by comparing the score of all meetings. The main scores improved from 65.83 at the $1^{\text {st }}$ cycle to 75.83 at the $2^{\text {nd }}$ cycle and to 83.75 at the $3^{\text {rd }}$ cycle.
\end{abstract}

Key words : reading comprehension, think-pair-share, lesson study

\section{PENDAHULUAN}

Mata kuliah reading 3 merupakan salah satu mata kuliah wajib yang harus diprogram pada semester 4 oleh mahasiswa di program studi d3 bahasa Inggris undiksha singaraja. Mata kuliah ini merupakan keberlanjutan dari mata kuliah reading 1, dan 2 yang telah diambil sebelumnya pada semester 2 dan 3 . Keterampilan membaca ini bertujuan untuk membekali mahasiswa dengan kemampuan dalam memahami berbagai macam teks dan mampu memperoleh informasi baik yang tersurat maupun yang tersirat, sehingga mereka memiliki keterampilan membaca yang lebih baik yang dibutuhkan untuk kebutuhan mereka kelak saat di dunia kerja atau saat mereka mencari atau menemukan bahan rujukan yang sesuai dengan bahan kajian tugas akhir mereka.

Berdasarkan observasi pada mata kuliah reading 3 untuk mahasiswa semester 4 tahun akademik 2016/2017, aktifitas pembelajaran lebih ditekankan 
pada kegiatan individu. Hal ini bisa dilihat dari aktifitas mahasiswa di kelas selama proses pembelajaran dari mulai membaca keseluruhan isi teks, menggarisbawahi beberapa kata, prase dan kalimat yang kurang jelas maknanya, mencari kata-kata yang masih asing di dalam kamus (menerjemahkan), dan kemudian menjawab pertanyaan yang disajikan di bawah teks bacaan. Dengan kata lain, waktu yang ada lebih banyak dihabiskan untuk memperhatikan apa yang tersurat dengan kurangnya perhatian pada pandangan dan nilai yang dapat dipelajari secara tersirat.

Situasi kelas seperti disampaikan di atas cenderung tidak melibatkan siswa secara aktif dalam proses pembelajaran, yang dapat dilihat dari kurangnya partisipasi siswa dalam bertanya kepada dosen atau mengomentari (menyetujui/menyanggah) pendapat atau jawaban teman sesama mahasiswa, sehingga siswa lebih banyak bekerja secara individual untuk memahami isi bacaan.

Fenomena di atas berkontribusi terhadap kondisi hasil belajar mahasiswa yang pernah mengambil mata kuliah reading 3 selama 3 tahun terakhir. Data yang ada pada daftar perolehan nilai akhir mahasiswa (DPNA) yang ada pada jurusan D3 bahasa Inggris mulai dari tahun ajaran 2013/2014, 2014/2015, 2015/1016 menunjukkan data sebagai berikut.

Tabel 1. Persentase Sebaran Nilai Mahasiswa Pada Mata Kuliah Reading 3 Selama 3 Tahun

\begin{tabular}{lccc}
\hline \multirow{1}{*}{ Sebaran Nilai } & \multicolumn{3}{c}{ Tahun Akademik } \\
\cline { 2 - 4 } Nilai A & $\mathbf{2 0 1 3 / 2 0 1 4}$ & $\mathbf{2 0 1 4 / 2 0 1 5}$ & $\mathbf{2 0 1 5 / 2 0 1 6}$ \\
Nilai B & $10 \%$ & $5 \%$ & $7 \%$ \\
Nilai C & $35 \%$ & $30 \%$ & $25 \%$ \\
Nilai D & $50 \%$ & $65 \%$ & $63 \%$ \\
Nilai E & $5 \%$ & $0 \%$ & $5 \%$ \\
\hline
\end{tabular}

Dari tabel di atas dapat dilihat bahwa $45 \%$ dari mahasiswa yang mendapatkan nilai dengan kategori baik keatas pada 2013/2014, sedangkan pada tahun akademik 2014/2015 terlihat hanya 35\%, dan 32\% di tahun 2015/2016. Dapat disimpulkan bahwa selama periode 3 tahun terakhir persentase mahasiswa yang mendapat nilai minimal B masih kurang dari 50\% sehingga dapat dikatakan 
bahwa kemampuan mahasiswa untuk memahami isi bacaan masih belum sesuai harapan dan menumbuhkan kemampuan tersebut bukanlah hal yang mudah.

Dorn dan Carla (2005) mengungkapkan pemahaman adalah suatu proses yang diatur oleh kognitif, emosi, persepsi, dan pengalaman sosial. Dengan demikian membaca pemahaman (reading comprehension) adalah suatu proses berfikir dengan melibatkan kognitif, perasaan, ide, dan pengalaman sehingga pembaca mampu memahami apa yang dibacanya dan memperoleh informasi dari teks dan diharapkan nantinya siswa mampu mendemonstrasikan pengetahuan atau pemahaman tentang informasi yang diperoleh.

Merujuk pada berbagai masalah yang dihadapi di atas seperti kurangnya perhatian pada informasi yang tersirat, pelibatan siswa secara lebih aktif serta rendahnya capaian belajar siswa, peneliti berpandangan bahwa perlunya upaya untuk memperbaiki kondisi proses dan hasil belajar mahasiswa D3 bahasa Inggris Undiksha singaraja pada mata kuliah reading 3. Lesson study dipandang sebagai alternatif solusi untuk diimplementasikan dalam perkuliahan reading 3. Dengan pelibatan dosen lainnya yang secara bersama-sama mengkaji pembelajaran mulai dari perencanaan sampai dengan evaluasi diharapkan menghasilkan pembelajaran yang efektif dan mampu mengatasi permasalahan yang ada. Menurut Lewis (2002), lesson study merupakan model peningkatan mutu pembelajaran melalui pengkajian pembelajran secara kolaboratif dan berkelanjutan berlandaskan prinsip-prinsip kolegalitas dan mutual learning, guna membangun learning community.

Pelaksanaan lesson study ini akan dikhususkan pada penerapan teknik “Think pair share" sebagai sebuah teknik pembelajaran yang dipandang cocok untuk pengajaran "Reading 3" yang lebih banyak menuntut mahasiswa ke arah membaca pemahaman. Sebagai bentuk pembelajaran kooperatif, Fisher (2005) menyatakan bahwa think-pair-share adalah teknik yang sangat efektif untuk diterapkan pada aktifitas membaca karena dapat disesuaikan dengan berbagai jenis setting belajar dan dengan segala usia dan kemampuan karena teknik ini tidak didasarkan pada interaksi satu arah antara pengajar dengan salah satu siwa saja, tapi melibatkan semua siswa yang mana setiap siswa dapat memberikan respon terhadap gagasan temannya. Hal tersebut merupakan keuntungan teknik ini 
sebagaimana yang dinyatakan oleh Lyman (1987) bahwa teknik ini bisa dilaksanakan dengan cepat dan tanpa persiapan yang lama, serta melatih siswa untuk berpikir kritis dan menumbuhkan rasa percaya diri dalam menyampaikan gagasan yang dimiliki di depan kelas. Dengan demikian ada jaminan bahwa suasana proses pembelajaran bisa lebih produktif karena semua siswa terlibat di dalamnya.

Teknik ini juga telah diterapkan oleh Yani dan Sesmiyanti (2014) pada mata kuliah reading comprehension, yang tebukti mampu meningkatkan kemampuan mahasiswa dalam memahami bacaan. Selain itu, mahasiswa juga merasa termotivasi karena bisa terlibat di dalam proses pembelajaran. Sejalan dengan ini, Cholis (2006) menemukan peningkatan kemampuan memahami bacaan karena mahasiswa memiliki lebih banyak waktu unntuk berpikir dan bekerja sama dengan teman lainnya sehingga mahasiswa lebih dirangsang untuk berani mengungkapkan ide/pikirannya, memberikan tanggapan serta menghargai setiap perbedaan pendapat.

\section{METODE PENELITIAN}

\section{Rancangan Penelitian}

Prosedur penelitian ini menggunakan metode pengembangan sistem pembelajaran yang diterapkan adalah dengan lesson study model Lewis (2002). Pelaksanaanya direncanakan berlangsung dalam 3 siklus yang disesuaikan dengan alokasi waktu dan pokok bahasan yang dipilih. Setiap siklus terdiri dari 3 kegiatan, yaitu: 1) Perencanaan (plan); 2) Pelaksanaan dan Observasi (do); 3) Refleksi (see).

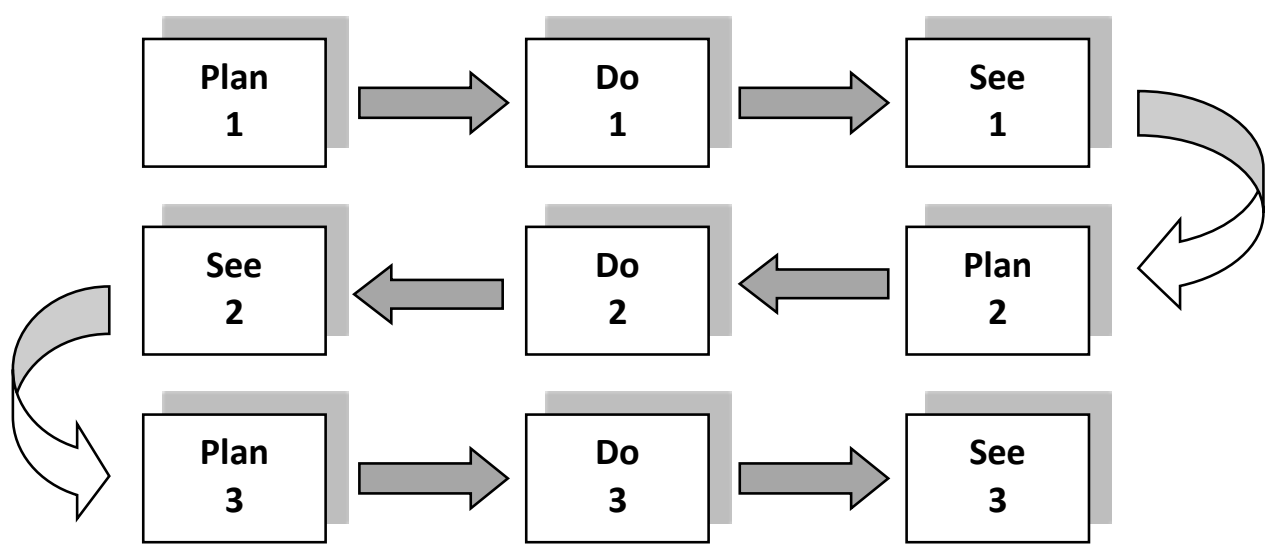

Gambar 1. Prosedur Penelitian 
Langkah selanjutnya penentuan siklus-siklus penelitian, yaitu sebagai berikut.

\section{a. Siklus Pertama}

1) Perencanaan (plan), tahap perencanaan pembelajaran anggota kelompok menyusun Rencana Pembelajaran (RP), bahan bacaan, instrument penilaian proses, dan lembar observasi pembelajaran.

2) Pelaksanaan dan Observasi (do), rencana pembelajaran yang telah disusun bersama diimplementasikan di kelas oleh dosen pelaksana pembelajaran. Anggota kelompok sebagai observer akan mengumpulkan data selama pembelajaran berlangsung.

3) Refleksi (see), bertujuan untuk mengatasi permasalahan, dengan memodifikasi perencanaan sebelumnya sesuai dengan data lapangan. Proses pembelajaran yang sudah terlaksana perlu dilakukan refleksi dan dianalisis segera setelah pembelajaran selesai. Hasil refleksi digunakan sebagai masukan untuk perbaikan atau revisi rencana pembelajaran berikutnya.

\section{b. Siklus Kedua}

Siklus kedua langkahnya dilakukan seperti tahapan-tahapan pada siklus pertama tetapi didahului dengan perencanaan ulang berdasarkan hasil-hasil yang diperoleh pada siklus pertama, sehingga kelemahan-kelemahan yang terjadi pada siklus pertama tidak terjadi pada siklus kedua.

\section{c. Siklus Ketiga}

Siklus ketiga langkahnya dilakukan seperti tahapan-tahapan pada siklus pertama dan kedua, tetapi didahului dengan perencanaan ulang berdasarkan hasilhasil yang diperoleh pada siklus kedua, sehingga kelemahan-kelemahan yang terjadi pada siklus kedua tidak terjadi pada siklus ketiga.

\section{Lokasi Penelitian}

Penelitian ini dilakukan di jurusan D3 Bahasa Inggris Fakultas Bahasa dan Seni Universitas pendidikan Ganesha. 


\section{Subjek Penelitian}

Subjek dalam penelitian ini adalah seluruh mahasiswa D3 Bahasa Inggris semester 4 sebanyak 12 orang yang mengambil mata kuliah Reading 3.

\section{Pengumpulan Data}

Pegumpulan data dilakukan dengan observasi, dan penilaian. Teknik observasi dilakukan tiga tahap, yaitu: saat berpikir, berpasangan dan berbagi. Sedangkan penilaian diambil dari tes membaca pemahaman. Instrumen yang digunakan dalam penelitian ini meliputi : lembar observasi, tes bacaan serta kuesioner. Data hasil observasi dianalisis secara deskriptif untuk mengetahui kualitas proses belajar mengajar dan kemajuan hasil belajar reading 3. Untuk mengetahui peningkatan pemahaman dilakukan dengan cara membandingkan pencapaian skor individu maupun kelompok dari hasil pertemuan demi pertemuan.

\section{HASIL DAN PEMBAHASAN}

Pada siklus I dilakukan tiga tahapan yang umum diterapkan dalam lesson study yaitu 1) tahap perencanaan (plan), tahap pelaksanaan (do) yang sering disebut dengan research lesson dan tahap refleksi (see) atau kegiatan pasca pelajaran (Kadarisman, 2009). Tiga tahapan ini merupakan satu siklus pembelajaran. Tahap perencanaan (plan) ini tim peneliti melakukan diskusi dan menghasilkan kesepakatan tentang tindakan untuk meningkatkan pemahaman mahasiswa dalam mata kuliah reading comprehensive. Berikutnya adalah penetuan tentang topik dan bahan bacaan yang menarik bagi mahasiswa, jumlah kelompok dan sebaran kelompok dengan meratakan komposisi pria dan wanita serta kemampuan akademiknya. Diskusi awal ini penting meningat esensi dari Lesson study adalah pengkajian pembelajaran secara kolaboratif dan berkelanjutan berlandaskan prinsip-prinsip kolegalitas dan mutual learning untuk membangun learning community (Rusman, 2010:384). Selain itu Sudrajat (dalam Sandi, 2010) mengatakan bahwa "lesson study merupakan salah satu upaya untuk meningkatkan proses dan hasil pembelajaran yang dilaksanakan secara kolaboratif dan berkelanjutan oleh sekelompok guru" 
Tahapan berikutnya adalah tindakan dan observasi (do) untuk siklus I. kegiatan ini dilakukan selama 2 kali pertemuan dengan materi April fool's day dan Mother's day. Pada kesempatan ini dosen melakukan proses pembelajaran sebagai berikut

a. Think. dosen membagi siswa dalam kelompok berempat (dan ada 3 kelompok) dan memberikan tugas kepada semua kelompok, setiap mahasiswa memikirkan dan mengerjakan tugas tersebut sendiri., (4) kedua pasangan bertemu kembali dalam kelompok berempat. mahasiswa mempunyai kesempatan untuk membagikan hasil kerjanya kepada kelompok berempat.

b. Pair. Dosen meminta mahasiswa berpasangan dengan salah satu rekan dalam kelompok untuk mendiskusikan apa yang telah dipikirkannya pada tahap pertama. Dalam tahap ini, setiap anggota pada kelompok membandingkan jawaban atau hasil pemikiran mereka dengan mendefinisikan jawaban yang dianggap paling benar, paling meyakinkan, atau paling unik. Dosen memberi waktu 8-10 menit untuk berpasangan.

c. Share. (berbagi) Pada tahap akhir, dosen meminta kepada pasangan untuk berbagi dengan seluruh kelas tentang apa yang telah mereka bicarakan. Siswa berbagi jawaban dengan seluruh kelas. Mahasiswa mempresentasikan jawaban atau pemecahan masalah secara individual atau kelompok didepan kelas. Keterampilan berbagi dalam seluruh kelas dilakukan dengan menunjuk pasangan yang secara sukarela bersedia melaporkan hasil kerja kelompoknya dan dilanjutkan secara bergiliran pasangan demi pasangan hingga sekitar seluruh pasangan telah mendapat kesempatan untuk melaporkan. Kemudian dosen menganalisis dan mengevaluasi hasil pemecahan masalah dan membantu mahasiswa untuk melakukan refleksi atau evaluasi terhadap hasil pemecahan masalah yang telah mereka diskusikan.

Hasil pengamatan pertemuan pertama masih banyak mahasiswa yang belum paham tentang teknik Think Pair Share yang diterapkan dosen. Kontrol kelas yang dilakukan dosen masih kurang, karena mahasiswa telihat gugup terutama saat diminta melakukan tugas berpikir sendiri (individu). Begitu juga pada saat mereka diminta untuk berdiskusi secara berpasangan, mereka merasa kurang percaya diri dengan jawaban dan pendapat pribadinya dan cenderung untuk menggunakan pendapat temannya saja tanpa diiringi dengan argumentasi yang memadai terhadap 
pilihan akan suatu jawaban. Yang terakhir adalah saat mahasiswa diminta untuk berbagi tentang apa yang menjadi pilihan kelompoknya, penyampaian ide dan jawaban hanya didominasi oleh mahasiswa yang aktif dan tergolong pintar sedangkan yang lainnya hanya menjadi pendengar yang baik. dari hasil tes pada siklus I didapat rincian hasil sebagai berikut : 0\% mahasiswa mendapatkan skor 85-100, 25\% memperoleh skor 70-84, dan 75\% mendapatkan skor 55-69.

Tahap terakhir adalah refleksi (see). Pada tahap ini dilakukan setelah selesai setiap pertemuan, dosen dan tim peneliti membahas hal-hal yang terjadi selama perkuliahan berlangsung. Hasilnya siklus I memang kurang memuaskan dan belum sesuai dengan harapan yang mana masih banyak mahasiswa yang pasif baik dalam kegiatan individu, berpasangan dan kelompok/klasikal. Begitu juga dengan hasil tes siklus I yang masih didominasi (75\%) oleh mahasiswa yang mendapatkan nilai 55-69.

Berdasarkan hasil refleksi pada siklus I, perlu dirancang siklus II dengan perbaikan dalam kegiatan pembelajaran terutama dalam pelibatan semua mahasiswa secara aktif dalam diskusi berpasangan dan kelompok.

Siklus II, aktivitas perencanaan tindakan (plan) yang dilakukakn oleh tim peneliti adalah melakukan perbaikan 1) partisipasi mahasiswa yang pada siklus I pasif diharapkan pada siklus II bisa menjadi lebih aktif dengan pendampingan oleh dosen pengajar yang lebih intensif untuk memberikan stuimulus yang cukup kepada mereka sehingga mereka lebih merasa dibantu, dan bersemangat untuk mengerjakan soal individu dan berpasangan. 2) pada kegiatan diskusi kelas atau dalam kelompok yang lebih besar, dosen harus menunjuk siswa satu per satu untuk untuk mengemukakan jawaban dan memberikan tanggapan terhadap pendapat teman yang lainnya. Dengan melakukakn perbaikan ini diharapkan keengganan mahasiswa untuk menjadi pasif pada diskusi di kelas dapat diminimalisir.

Sedangkan untuk tahap pelaksanaan dan observasi (do) pada siklus II, tim peneliti melakukan hal yang sama dengan siklus I yaitu dengan melakukan 2 kali pertemuan dengan materi Valentine"s day dan Thanks Giving. Sama halnya dengan siklus I, ada tiga tahapan yang dilakukan oleh dosen dalam pembelajaran. Namun dalam hal, sedikit perubahan dilakukan pada sesi berpasangan atau Pair nya dengan lebih ditekankan pada argumentasi dari masing-masing individu untuk 
menyampaikan idenya, sehingga guna meyakinkan hal tersebut, dosen memantau lebih dekat lagi bahwa mereka telah menyampaikan semua ide dan gagasannya dengan semua bekal pengetahuan yang mereka miliki selain keterampilan untuk menghubungkan pengetahuan yang dimiliki dengan topik yang sedang dibaca sehingga mahasiswa mampu menganalisis makna dan isi bacaan (Crawley dan Mountain dalam Zuchdi, 2004).

Hasil pengamatan pada pertemuan pertama dan kedua menunjukkan bahwa sudah ada cukup perubahan pada siklus II. Namun demikian, masih juga dijumpai beberapa mahasiswa telihat gugup terutama saat diminta melakukan tugas berpikir sendiri (individu) dan didampingi oleh dosen untuk menggali lebih dalam dan banyak kemungkinan jawaban/ide. Hal yang sama dijumpai saat diskusi berpasangan, meskipun mahasiswa sudah mulai berani berdiskusi lebih panjang dan argumentatif namun tetap saja mereka harus diminta oleh dosen untuk berbicara dan diberikan beberapa stimulus. Yang terakhir adalah saat mahasiswa diminta untuk berbagi tentang apa yang menjadi pilihan kelompoknya, penyampaian ide dan jawaban sudah tidak lagi didominasi oleh mahasiswa yang aktif dan tergolong pintar karena dosen telah menunjuk semua mahasiswa untuk mendapat giliran untuk berbicara baik tentang jawaban pasangannya ataupun tanggapan terhadap jawaban pasangan lainnya. Merujuk pada hasil tes pada siklus II, didapat rincian hasil sebagai berikut : 25\% mahasiswa mendapatkan skor 85100, 50\% memperoleh skor 70-84, dan 25\% mendapatkan skor 55-69. Pada siklus II ini terdapat 3 orang yang mendapat nilai A, dan peningkatan jumlah mahasiswa yang mendapat nilai $\mathrm{B}$, yaitu 6 orang, serta terdapat pengurangan jumlah mahasiswa yang mendapat nilai $\mathrm{C}$, yang dulunya 9 orang menurun menjadi 3 orang.

Tahap terakhir adalah refleksi (see). Pada tahap ini dilakukan setelah selesai setiap pertemuan, dosen dan tim peneliti membahas hal-hal yang terjadi selama perkuliahan berlangsung. Hasilnya siklus II memang cukup menggembirakan dan sudah semakin mendekati harapan yang mana mahasiswa sudah mulai aktif untuk mengungkapkan idenya, baik dalam kegiatan individu, berpasangan dan kelompok/klasikal meskipun masih dipandu oleh dosen untuk merangsang mahasiswa mengungkapkan lebih bayak ide. . Begitu juga dengan 
hasil tes siklus II, meskipun sudah ada perubahan, masih juga didapat 3 mahasiswa yang mendapat skor 55-69.

Berdasarkan hasil refleksi pada siklus II, perlu dirancang siklus III dengan perbaikan dalam kegiatan pembelajaran terutama dalam pelibatan semua mahasiswa secara aktif dalam diskusi berpasangan dan kelompok dengan mengurangi kontrol dosen untuk setiap tahapan pembelajaran sehingga ditumbulkan kemandirian dalam memahami isi bacaan.

Pada siklus III, aktivitas perencanaan tindakan (plan) yang dilakukakn oleh tim peneliti adalah melakukan perbaikan 1) mempertahankan partisipasi mahasiswa, dengan lebih menekankan pada kemandirian dan dorongan diri, kepercayaan diri untuk mampu mengemukakan gagasan dan ide, serta jawaban. 2) mengurangi pendampingan dosen dalam memandu dan memberikan rangsangan secara individu, dan digantikan dengan brainstorming yang cukup untuk setiap topik yang akan dibahas, sehingga semua siswa memiliki gambaran awal serta wawasan yang sama terhadap bacaan sehingga diharapkan membantu mereka dalam proses pemahaman bacaan nanti.

Sedangkan untuk tahap pelaksanaan dan observasi (do) pada siklus III, tim peneliti melakukan hal yang sama dengan siklus I dan II yaitu dengan melakukan 2 kali pertemuan dengan materi Education dan Juvenile crime. Ada tiga tahapan yang sama dilakukan oleh dosen dalam pembelajaran ini yaitu: 1) Think, 2) pair, 3) share. Dalam siklus III ini peran dosen dalam pendampingan secara individu sudah tidak ada, lebih banyak memantau jalannya proses diskusi dan meyakinkan bahwa semua mahasiswa mendapatkan kesempatan untuk menyampaikan ide dan gagasan tentang topik bacaan

Hasil pengamatan pertemuan pertama dan kedua menunjukkan bahwa sudah ada peningkatan yang sangat pesat dari siklus II. Mahasiswa sangat paham tentang teknik Think Pair Share yang diterapkan dosen. Dengan melakukan brainstorming dan mengurangi kontrol terhadap kelas guna membangkitkan motivasi keterlibatan semua mahasiswa secara sukarela dalam semua tahapan pembelajaran, pada kesempatan ini tidak lagi dijumpai mahasiswa yang enggan, gugup, atau tidak percaya diri untuk menggali lebih dalam dan banyak kemungkinan jawaban/ide dalam semua tahapan pembelajaran. Mahasiswa juga 
sudah mulai berani berdiskusi lebih panjang dan argumentatif tanpa harus dipandu dan dirangsang oleh dosen. Yang terakhir adalah saat mahasiswa diminta untuk berbagi tentang apa yang menjadi pilihan kelompoknya, penyampaian ide dan jawaban, semua mahasiswa mengajukan diri secara sukarela baik untuk mempresetasikan gagasan/jawaban kelompoknya, atau dalam memberi tanggapan dan bereaksi secara verbal atas tanggapan tersebut. Peningjkatan juga terjadi dari hasil tes pada siklus III, didapat rincian hasil sebagai berikut : 50\% mahasiswa mendapatkan skor $85-100,50 \%$ memperoleh skor 70-84, dan 0\% mendapatkan skor 55-69.

Tahap terakhir adalah refleksi (see). Pada tahap ini dilakukan setelah selesai setiap pertemuan, dosen dan tim peneliti membahas hal-hal yang terjadi selama perkulaiahan berlangsung. Hasilnya siklus III sangat menggembirakan dan sudah sesuai dengan harapan dimana harapan yang mana mahasiswa sudah mulai aktif secara sukarela untuk mengungkapkan idenya, baik dalam kegiatan individu, berpasangan dan kelompok/klasikal tanpa harus dipandu oleh dosen untuk merangsang mahasiswa mengungkapkan lebih bayak ide. Kenyataan ini sejalan dengan apa yang diungkapkan oleh Harras dan Sulistianingsih (1997) bahwa yang terpenting dalam aktivitas membaca adalah menangkap pesan atau gagasan utama bacaan secara lebih baik. Begitu juga dengan hasil tes siklus III, sudah ada peningkatan yang sangat pesat karena semua siswa mendapatkan nilai diatas B.

Tanggapan mahasiswa terhadap penerapan teknik think, pair and share berbasis lesson study ini yang diberikan di akhir siklus III, melalui angket terbuka menunjukkan bahwa mahasiswa memberi tanggapan positif karena merasa senang dan melatih mereka untuk berpikir lebih kritis sehingga dapat memahamai isi bacaan yang diberikan. Hasil yang diperoleh adalah $75 \%$ mengatakan senang dan $25 \%$ mengatakan sangat senang dengan penerapan teknik ini. Disamping membiasakan mereka untuk mandiri dan percaya diri, teknik ini juga membuat mereka senang karena diberikan kesempatan yang lebih untuk berdiskusi baik dengan sesame teman dan dosen pengajar, yang mana hal ini tidak mereka dapatkan sebelumnya. Berdasarkan hasil refleksi pada siklus III dipandang tidak perlu lagi untuk merancang siklus berikutnya. 
Kendati penelitian ini menunjukkan hasil yang memuaskan/baik, namun keberlanjutan pengajaran melalui teknik ini untuk selalu diterapkan di kelas sehingga potensi yang dimiliki oleh mahasiswa dalam memahami isi bacaan pada mata kuliah reading 3 tetap bisa dikembangkan.

\section{PENUTUP}

Berdasarkan implementasi dari teknik Think Pair Share dalam mengajar Reading 3 dan temuan-temuan dari penelitian ini, peneliti menyimpulkan bahwa 1. Teknik ini dapat meningkat pemahaman mahasiswa pada mata kuliah Reading 3, yang dipengaruhi topik yang menarik yang dijadikan sebagai materi pembelajaran, dosen yang kreatif yang mampu membimbing mahasiswa, dan strategi yang diterapkan dalam proses pembelajaran.

2. Proses peningkatan pemahaman isi bacaan dilakukan melalui bimbingan terkontrol dengan pemberian kebiasaan berpikir yang tepat dan menempatkan mahsiswa sebagai subjek dan dosen hanya sebagai motivator dan fasilitator sehingga pembelajaran berjalan sesuai dengan yang direncanakan

3. Tanggapan mahasiswa terhadap penerapan teknik think, pair, and share berbasis lesson study ini diketahui bahwa mereka memberikan sambutan yang positif yang diketahui dari hasil angket terbuka dimana $75 \%$ mahasiswa merasa senang dan termotivasi dengan penerapan tejnik ini dan $25 \%$ lainnya merasa sangat senang.

Merujuk pada hasil penelitian ini yang memuaskan, keuntungan dan beberapa sambutan positif mahasiswa, maka disarankan kedepannya untuk menerapkan teknik think, pair, and share berbasis lesson study untuk meningkatkan pemahaman mahasiswa D3 Bahasa Inggris dalam mata kuliah Reading 3.

\section{DAFTAR PUSTAKA}

Cholis, S. 2006. Penerapan Pembelajaran Kooperatif Think Pair Share (TPS). Malang: Lembaga Penelitian UM.

Dorn, L. J dan Carla, S. 2005. Teaching for Deep Comprehension A Reading Workshop Approach. Portland: Stenhouse Publisher.

Fisher, R. 2005. Teaching Children to Learn. $2^{\text {nd }}$ edition, Bolton:UK. Nelson Thorns publishers. 
Harras, KA. dan Sulistianingsih, L. 1997. Membaca 1. Jakarta: Universitas Terbuka.

Kadarisman, N. 2009. Teknik Dokumentasi dan Analisis Rekaman video untuk Refleksi dalam Lesson Study. Makalah Dessiminasi Lesson Study UNY. Diselenggarakan dalam Rangka Sosialisasi Lesson Study di Fakultas Lingkungan UNY.

Lewis, C. C, 2002, Lesson Study : A Handbook of Teacher-Led Instructional Change, Philadelphia, PA : research for better Schools, Inc.

Lyman, F. Strategies for Reading Comprehension. Pada http://www.teachervision.fen.com/group work/cooperativelearning/48547.html. (dibuka pada Februari 2017).

Rusman. 2010. Model-Model Pemebelajaran Mengembangkan Profesionalisme Guru. Bandung: Raja Grafindo Persada.

Sandi, W. 2010. Pengembangan bahan Workshop lesson study serta implementasi oleh Guru Matematika di Madrasah Ibtidaiyah Negeri 1 Pangkalpinang. Tesis tidak diterbitkan. Palembang : Fakultas Keguruan dan Ilmu Pendidikan. Universitas.

Yani, T.H., Sesmiyanti 2014 Penerapan teknik think pair share untuk meningkatkan kemampuan membaca pada mata kuliah reading comprehension jurnal pelangi, research of education and development Vol. 6 No.2 Tahun 2014 Halaman: 171-181.

Zuchdi, D. 2004. "Peningkatan Kemampuan Memahami Bacaan dan Kemandirian dengan Teknik Rencana Prabaca." Litera. Volume 3. No.2, Juli. Halaman 188-200. 